\title{
SYSTEMATIC REVISION OF THE SUCKER CREEK AND TROUT CREEK MIOCENE FLORAS OF SOUTHEASTERN OREGON ${ }^{1}$
}

\author{
Alan Graham \\ Department of Botany, University of Michigan, Ann Arbor, Michigan
}

A B S T R A C T

\begin{abstract}
Graham, Alan. (U. Michigan, Ann Arbor.) Systematic revision of the Sucker Creek and Trout Creek Miocene floras of southeastern Oregon. Amer. Jour. Bot. 50(9): 921-936. Illus. 1963.—The Sucker Creek flora is preserved in shales of volcanic origin exposed in Malheur County, southeastern Oregon. A study of the flora has been made and the systematic revisions presented. The following new species are described: Osmunda claytonites, Davallia solidites, Shepherdia argenteaites, Magnolia ovulata, Anoda suckerensis, and Platanus youngii. A new combination, Hiraea knowltoni (Berry), is proposed. Additional synonymies, Incertae Sedis, and other taxonomic changes are included. The Trout Creek flora is to the west of Sucker Creek in Harney County, southeastern Oregon. The fossils are preserved in diatomite. Four new species are described: Equisetum miocenicum, Gossypium arnoldii, Urena miocenica, and Spiraea miocenica. New combinations are Pleridium calabazensis (Dorf), and Nymphaea rotunda (Arnold). A revised species list is given for the 2 floras. The Sucker Creek flora contains 47 families, 60 genera, and 69 species, presently identified. The Trout Creek flora contains 29 families, 51 genera, and 75 species. The distributional, ecologic, and geologic interpretations of the 2 floras will be presented in a subsequent publication.
\end{abstract}

During Middle and Late Tertiary times extensive areas in western North America were subjected to intensive vulcanism expressed in part by outpourings of lava and ejection of quantities of volcanic ash. Streams of lava blocked rivers and drainage systems and created numerous lakes. The vegetation surrounding these lakes contributed wood, leaves, seeds, fruits, pollen, and spores to the accumulating bottom sediments. In some lakes, conditions were favorable for the development of extensive diatom floras, and the shells of these organisms, together with volcanic ash and plant parts, contributed to the filling of the lake basins. The result of these biologic and geologic activities was the development of numerous plant-bearing ash and diatom beds overlain, underlain, or intercalated between thick sequences of lava.

In 1932, The University of Michigan Museum of Paleontology contracted with Percy Train to make collections from one such flora at Trout Creek in Harney County, southeastern Oregon. Train's original collection numbered 10,000 specimens and in 1933 he added 1000 more. In 1935, Train collected 750. specimens from the vicinity of Rockville, Malheur County, southeastern Oregon, in the Sucker Creek Valley. Smaller additions were later made to the Michigan collections by C. A. Arnold, Helen V. Smith, and the author. Altogether, 13,000 specimens were available from the 2 floras, and from this number, 8,500 wellpreserved specimens were selected for study. This number was supplemented by examination of approximately 40,000 pollen grains and spores from the Sucker Creek flora. Sediments from Trout Creek were barren of pollen.

\footnotetext{
1 Received for pủblication, February 19, 1963.
}

The purpose of this paper is to record the systematic changes that have been made for these 2 floras and to provide a summary of their species composition. The significance and interpretations of these fossil plants in southeastern Oregon will be treated in a subsequent paper. The megafossils and holotypes of the microfossils have been deposited in the University of Michigan Museum of Paleontology collections.

THE SUCKER CREEK FLORA-Sucker Creek is an intermittent stream that flows north for a distance of about 25 miles and empties into the Snake River just north of Homedale, Idaho. The vicinity of the fossil deposits is reached by going south along U. S. Highway 95 about 3 miles beyond the Idaho-Oregon state line. The road crosses Sucker Creek at this point and a few feet beyond the bridge an unimproved road departs to the right (north). This road parallels Sucker Creek to the abandoned Rockville post-office and a few miles beyond to the Rockville schoolhouse. The fossil plant localities are scattered a few miles on either side of this road from the Fenwick Ranch to the schoolhouse, a distance of about 9 miles.

Fossil plants have been known from the vicinity of Rockville for almost 65 years. Waldermar Lindgren, geologist for the United States Geological Survey, made collections in the region in 1898 and sent the material to Frank Hall Knowlton for study. Knowlton included this material as part of the Payette flora and assigned the beds to the Upper Miocene. Smaller collections were later made by Ralph W. Chaney and by $\mathrm{E}$. W. Berry. In 1923, Horton C. Hinshaw collected several hundred specimens from the Ballantyne Ranch in Malheur County, Oregon. These were deposited in the Carnegie Museum and served as the basis for the first extensive study of the 

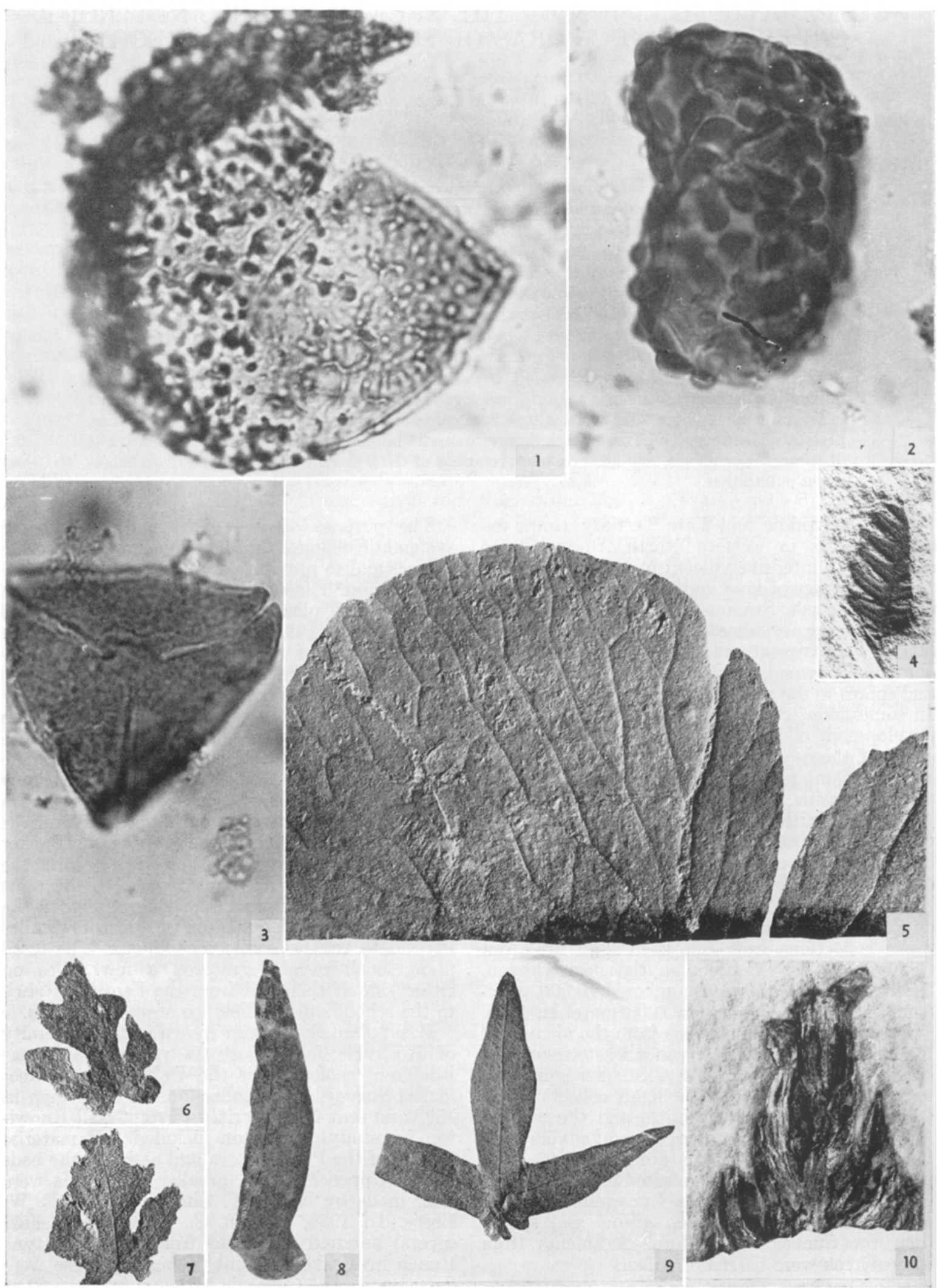

Fig. 1-10. Fossil plants from the Sucker Creek and Trout Creek floras. Megafossils are natural size unless otherwise indicated. Size of microfossils is given in microns.-Fig. 1. Osmunda claytonites sp. nov. Sucker Creek, UMMP Holotype 
Sucker Creek flora which was made by Betty Watt Brooks (1935). Mrs. Brooks recognized 14 families, 20 genera, and 28 species.

During the summers of 1931, 1932, 1934, and 1936 , Helen V. Smith collected at 3 localities in the Sucker Creek area. The type specimens from her study were deposited in the University of Michigan Museum of Paleontology collections, but other specimens were distributed among several institutions. Mrs. Smith (1938, 1939b) recognized 15 families, 19 genera, and 30 species.

The most recent contribution to the Sucker Creek flora, prior to the present study, was by Chaney and Axelrod (1959). They studied primarily the Mascall, Blue Mountains, and Stinking Water floras, but considered incidentally all the floras of similar age in the Columbia Plateau region. In their study, Chaney and Axelrod recognized 29 families, 39 genera, and 55 species.

In the present treatment 47 families, 60 genera, and 69 species, including microfossils, are recognized.

Nomenclatorial practices relating to Tertiary megafossil studies are well known and need little explanation. Briefly, if the fossil specimen is similar to a modern genus, i.e., Arbutus, it is given that generic name. The specific name, however, is diflerent from any modern species, in recognition of the fact that our concepts concerning the exact living counterparts of the fossils vary as new data become available. By using a separate name for the fossil species, and citing suggested affinities in the discussion of the specimen, much nomenclatorial revision is avoided. When unknowns are found, they are referred to an artificial genus (Phyl'ites in the case of leaves, Carpolithus in the (ase of seeds and fruits) or, as seems to be the current trend, the specimens and/or photographs are circulated privately and identifications published as they become available. This again avoids a certain amount of nomenclatorial revision.

For microfossils, no single system has been adapted for 3 main reasons: (1) Palynology is a technique used in a wide variety of subjects (taxollomy, paleobotany, archeology, meteorology, geology) and the most appropriate system of nomenclature varies with the kind of data desired. (2) Pleistocene, Tertiary, and Paleozoic pollen and spore analysis are relatively distinct fields owing to the different degrees to which the fossil specimens can be related to present-day species. Thus, different systems of nomenclature have tended to develop for each of the major divisions of geologic time. (3) Too few pollen and spore studies have been made on western North American Tertiary deposits to demonstrate the greater uscfulness of any one system. Most American investigators tend to follow the simple procedure of referring the microfossil to the smallest taxonomic unit to which it can be identified, without using artificial generic names. For example, Tertiary microfossils are often identified as "Gramincae," "Amaranthaceae-Chenopodiaceae," "Umbelliferae," "Fagus," "Betula," "Alnus," etc. This procedure is followed in the present treatment, with the addition that in those few instances in which a fossil pollen grain or spore can be referred to a living species, the specific name of the species is used suffixed by "-ites." l'or example, the fossil pollen grain of Shepherdia argentea Nuttall is descr bed as $S$. argenteaites.

Species descriptions-The following new species are proposed for the Sucker Creek flora.

\section{Division Tracheophyta \\ Sub-Division Pteropsida}

Class Filicineae

Order Osmundales

Family Osmundaceae

\section{Osmunda claytonites sp. nov. (Fig. 1)}

Species diagnosis-Spore spherical; tri-radiate, arms of triradiate scar $21 \mu$ long, narrow, margins entire, tapering to acute apices; baculate, with occasional clavate and irregular elements interspersed, sculpture elements ca. $1 \mu$ in length, numerous, irregularly distributed; $59 \mu$.

The spores of Osmunda can be distinguished from other fern spores, but distinctions among the species is difficult. The situation is made more difficult by the need of further systematic studies on the living members of Osmunda, and particularly the relationship between the American species and those of eastern Asia and the Pacific Islands. In general, however, the particular type of spore illustrated in Fig. 1 is most commonly produced by $O$. claytoniana L. Sets of modern reference slides were prepared from plants growing in 3 different habitats. In each instance, the spores of $O$. claytoniana could be separated, and this species, with its relatively dense and coarse sculpture elements, matched the fossil most closely. Since the specimen could be related to a modern species, it has been given specific status.

Osmunda claytoniana presently grows in moist woods and thickets from Newfoundland south to Georgia, Kentucky, and Arkansas. Since only a single spore, and no megafossils, were found,

No. 45608. $59 \mu$.-Fig. 2. Davallia solidites sp. nov. Sucker Croek, UMMP Holotype No. $45609.52 \times 31 \mu .-F i g .3$. Shepherdia argenteaites sp. nov. Sucker Creek, UMMP Holotype No. 45608. $32 \mu$. - Fig. 4. Pteridium calabazensis (Dorf) comb. nov. Trout Creek, UMMP No. 44873.-Fig. 5. Nymphaea rotunda (Arnold) comb. nov. Trout Creek, UMMP Holotype No. 18373.-Fig. 6, 7. Urena miocenica sp. nov. Trout Creek, UMMP Holotype No. 44948.-Fig. 8. Anoda suckerensis sp. nov. Sucker Creek, UMMP Holotype No. 44848.-Fig. 9. Gossypium arnoldii sp. nov. Trout Crek, UMMP Holotyre No. 44857.-Fig. 10. Magnolia ovulata sp. nov. Sucker Creek, UMMP Holotype No. 18374. 
Osmunda was probably not common in the Sucker Creek region during the Miocene.

Sucker Creek-1 spore

Holotype-locality 2D, slide 13B, UMMP No. 45608. Position on slide designated by dot of India ink, spore immediately to the right as viewed through the microscope.

Order Filicales

Family Davalliaceae

Davallia solidites sp. nov. (Fig. 2)

Species diagnosis-Spore reniform; monosulcate, sulcus ca. $21 \mu$ long (estimated); numerous large, low, broad sculpture elements (baculae) irregularly distributed and oriented at various angles; $52 \times 31 \mu$.

The taxonomic relationships among modern members of the Davalliaceae are not well understood. If the genus Davallia is interpreted sensu lato, its spores are relatively distinct and similar to the Sucker Creek specimen. The closely related genera Humata and Scyphularia are of ten segregated, however, and must then be considered in suggesting relationships between the specimen and modern fern genera. A survey of spore types in Humata and Scyphularia revealed that although they were similar to the fossil, quantitative differences existed that tended to suggest closest affinity with Davallia, even when interpreted sensu stricto.

Davallia includes about 80 species of primarily epiphytic ferns of the Old World tropics. The species vary to some extent in spore morphology, and $D$. solida (Forster) Swartz is relatively distinct. This is the most common and abundant species in the genus and, although often epiphytic, terrestrial forms are known. It grows from Malaysia to Japan, Fiji, and other islands of the South Pacific. It is the only species of Davallia that grows outside the tropical rainforest, and this fact, together with its occurrence in Japan, and probably China, where many other living equivalents of the Sucker Creek fossils are found, makes it an acceptable member of the flora. Furthermore, the spores of 5 other species were examined and only $D$. solida compared closely with the fossil specimens. Since other species are rare and/or grow under ecological conditions that were not widespread in the Columbia Plateau region during the Upper Miocene (tropical rainforest), $D$. solida seems the most likely living equivalent.

The only other fossil record of Davallia in western North America is D. montana Knowlton $(1899)^{2}$ from the Lower Tertiary (Paleocene or Eocene) of Yellowstone National Park. The specimen is very fragmentary, however, and as Knowlton notes (p. 672), its generic affinities are difficult to determine.

${ }^{2}$ Misspelled Devallia by Knowlton (LaMotte, 1952, p. 144).
Sucker Creek-2 specimens

Holotype-locality 10 , slide 9B, UMMP No. 45609. Position on slide designated by dot of India ink, spore immediately to the right as viewed through the microscope.

Division Tracheophyta

Sub-Division Pteropsida

Class Angiospermae

Family Eleagnaceae

\section{Shepherdia argenteaites sp. nov. (Fig. 3)}

Species diagnosis-lollen grain triangular, sides usually slightly convex; tricolporate, pores circular, $4 \mu$ in diameter, margin entire, equatorially arranged, equidistant, located at the apices of the triangular grain, slightly protruding due to an arching of the exine at the pores, colpi long $(16 \mu)$, narrow, margin slightly diffuse, extending almost to the poles of the grain (polar index very small); vestibulate, vestibulum small, giving the grain a hyaline appearance at the tips of the apices; tectate; scabrate; $32 \mu$.

The Eleagnaceae is a family of 3 genera, Eleagnus, Shepherdia, and Hippophaë. Pollen of Eleagnus and of 1 species of Shepherdia (S. argentea Nuttall) are similar to the fossil specimen. The pollen of Eleagnus, however, has colpi that are short, and the exine is relatively thick. The colpi of S. argentea extend almost to the poles of the grain and the exine is thinner. In these respects the pollen of $S$. argentea is most similar to the fossil specimens.

Shepherdia argentea is widespread over much of boreal North America. It extends southward into central United States along streams and at altitudes between 3500 and $6500 \mathrm{ft}$. In this region, it is commonly associated with sagebrush scrub and pinyon-juniper woodlands.

Sucker Creek-44 grains.

Holotype-locality 11, slide 4, UMMP No. 45608. Position on the slide designated by a dot of India ink, grain immediately to the right as viewed through the microscope.

\section{Family Magnoliaceae}

Magnolia ovulata sp. nov.(Fig. 10)

Synonymy-Magnolia sp. Arnold. 1937. Contrib. Univ. Mich. Mus. Paleo. 5: p. 85.

Species diagnosis-Specimen $5 \mathrm{~cm}$ in length, $4 \mathrm{~cm}$ broad at base, tapering to apex; central axis (receptacle) ca. $0.5 \mathrm{~cm}$ in diameter, bearing spirally arranged lateral appendages (carpels or follicles) departing from the axis at about $65^{\circ}$ angle and immediately curving upward; appendages ca. 2.5 $\mathrm{cm}$ long near the center of the specimen, $0.5 \mathrm{~cm}$ broad; surface irregularities possibly representing seeds overlain by the carpel wall.

The record of Magnolia at Sucker Creek is limited to a single specimen interpreted by Arnold 
(1937) as the apex of the ovulate portion of the conelike inflorescence. Identification of such a structure is difficult, but Magnolia is represented by leaves in the Latah flora and it is an ecologically and floristically acceptable genus for the Sucker Creek flora. The specimen is given specific status primarily for convenience of reference, since it is the only fossil of a Magnolia cone known from the western American Tertiary floras.

Sucker Creek-1 specimen, UMMP Holotype No. 18374 Family Malvaceae

\section{Anoda suckerensis sp. nov.(Fig. 8)}

Species diagnosis-Leaf $5.5 \times 1.5 \mathrm{~cm}$ (excluding petiole); petiole $1.3 \mathrm{~cm}$ in length; base auriculate, tip acuminate, margin entire; midvein straight, extending to tip of leaf, secondaries looping, curving upward near margin, departing at $45^{\circ}$ angle, tertiary venation a fine meshwork; thin to medium texture.

Anoda is a genus of 14 species, all of which are American and mostly Mexican. The specimen is most similar to A. cristata (L.) Schlecht. This modern species grows from southern Texas and New Mexico, throughout Mexico, and into Panama, Salvador, Guatemala, and British Honduras. It occurs from sea-level to about $2000 \mathrm{~m}$. $A$. cristata has a broad ecological tolerance and grows in such diverse habitats as wet meadows, riversides, old fields, oak forests and oak chaparral, open pastures, and in the shade of semi-desert shrubs. Anoda has not previously been reported as a fossil.

Sucker Creek-1 specimen, UMMP Holotype No. 44848

Tamily Platanaceae

Platanus youngii sp. nov. (Fig. 12)

Synonymy - Platanus aceroides Goeppert. Arnold, C. A. 1937. Contrib. Univ. Mich. Mus. Paleo. 5, p. 88 , pl. 3, Fig. 1 .

Platanus dissecta Lesquereux. Chaney, R. W. and D. I. Axelrod. 1959. Carnegie Inst. Wash. Publ. 617 , p. 182 (reference to Arnold's specimen from Sucker Creek only).

Species diagnosis-Leaf $10 \mathrm{~cm}$ in length (including petiole), width $8 \mathrm{~cm}$; petiole $1.7 \mathrm{~cm}$ in length, diameter ca. $2 \mathrm{~mm}$, expanding near the base; leaf trilobed, lobes acute, median lobe slightly longer than laterals; base slightly oblique, truncate to slightly cordate; margin serrate, serrations numerous, acute, simple; venation tripalmate, median vein straight, stronger than laterals, extending to tip of median lobe, laterals slightly looping, diverging at about $60^{\circ}$ angle and extending to tip of lateral lobes, looping sub-secondaries developed on proximal side of 2 lateral veins, extending into the marginal teeth or giving off smaller veins near the margin that serve the teeth, tertiary veins relatively coarse, parallel, extending at approximately right angle from secondaries and forming ladderlike connections between them, especially in upper portions of leaf, in lower portions slightly reticulate, quaternary venation a very fine reticulum.

This specimen was originally reported from Sucker Creek by Arnold (1937) who referred it to $P$. aceroides Goeppert. This fossil species is similar to the modern $P$. occidentalis $\mathrm{L}$., but as MacGinitie (1962, p. 112) notes, the limits of the fossil species and its relation to living sycamores is not clear. Chaney and Axelrod (1959) synomymized the Sucker Creek specimen with $P$. dissecta, the fossil equivalent of $P$. racemosa Nuttall. Herbarium material of $P$. occidentalis and $P$. racemosa was examined and specimens could not be found that matched the fossil exactly. The relatively close-set, acute, marginal serrations distinguish the fossil specimen from any living species observed. It is the opinion of the author that the specimen is either an aberrant form of $P$. dissecta, or that it possibly represents an extinct species. Nevertheless, it is morphologically distinct from typical $P$. dissecta material, and its inclusion in that species would extend the morphological range of $P$. dissecta beyond that otherwise suggested by $P$. racemosa.

A somewhat similar species has been described from the Miocene Kilgore flora of Nebraska by MacGinitie (1962, p. 112) as $P$. vitifolia. The relationship between this fossil species, the Sucker Creek specimen, and modern sycamores is uncertain, and monographic work on the fossils is needed.

The specimen is named for Mr. Bake Young, Nampa, Idaho.

Sucker Creek-1 specimen, UMMP Holotype No. 18367

New combinations - The following new combinations are proposed for the Sucker Creek flora.

Family Malpighiaceae

Hiraea knowltoni (Berry) comb. nov. (Fig. 11, 13)

Synonymy-Nyssa knowltoni Berry. 1929a. U. S. Geol. Surv. Prof. Paper 154-H, p. 261, pl. 59, Fig. 7.

Arnold, C. A. 1937. Contrib. Univ. Mich. Mus. Paleo. 5, p. 97, pl. 8, Fig. 1, 5.

Ptelea miocenica Berry. Brown, R. W. 1946. Jour. Wash. Acad. Sci. 36, p. 352-353. Chaney, R. W., and D. I. Axelrod. 1959. Carnegie Inst. Wash. Publ. 617, p. 188189 (reference to Latah specimen).

Nyssa knowltoni Berry (1929a) was described from leaf remains found in the Miocene Latah flora of Washington. Brown (1946) transferred this material to Ptelea miocenica, described by Berry (1931) for the characteristic winged fruits of that genus. Chaney and Axelrod (1959) accepted this treatment and included in their synonymy specimens figured by Arnold (1937) as $N$. knowltoni from the Sucker Creek and Trout Creek floras. 


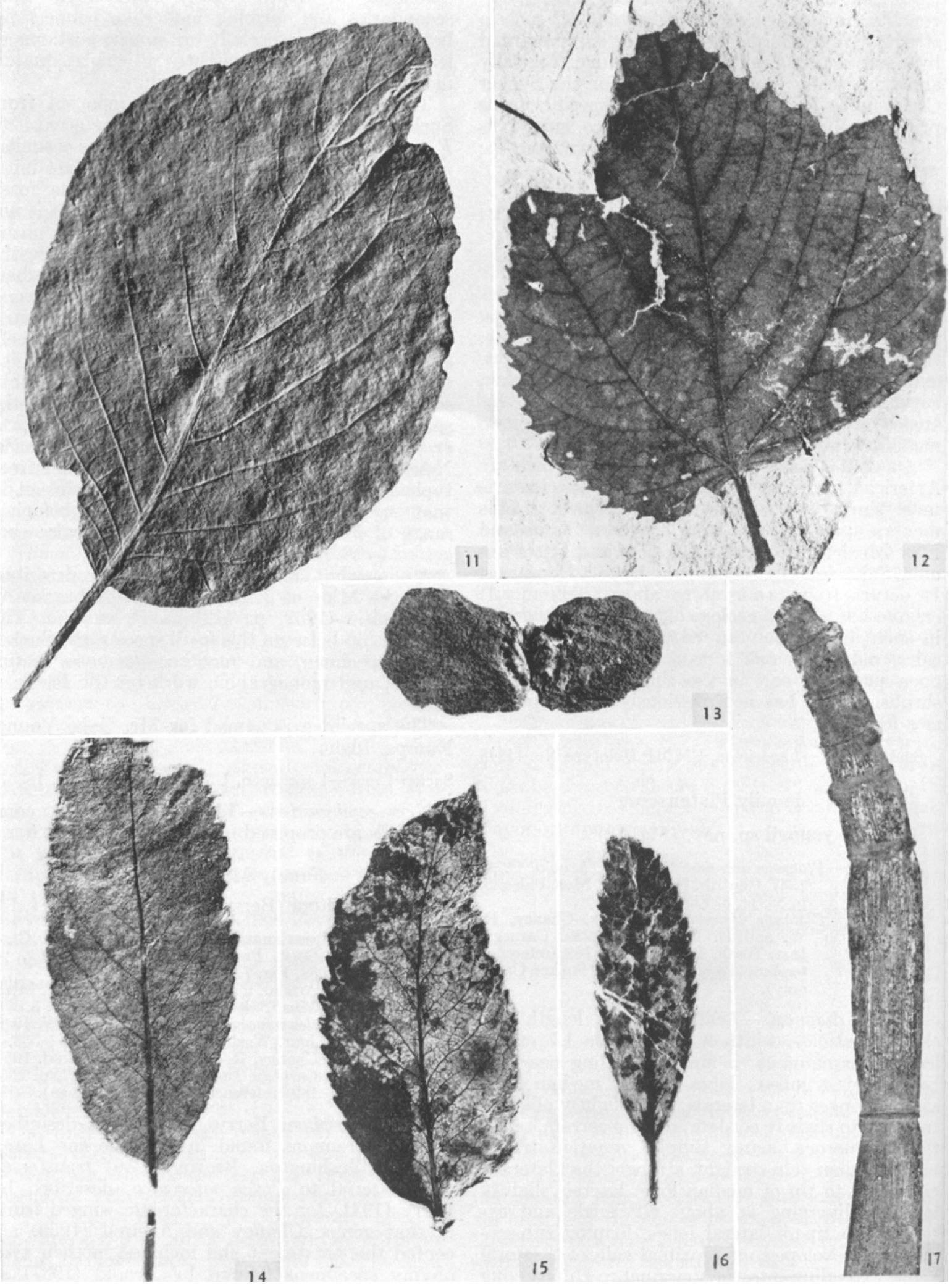

Fig. 11-17.-Fig. 11, 13. Hiraea knowltoni (Berry) comb. nov. Trout Creek, UMMP Nos. 18389, 44862, seed 2X.-Fig. 12. Platanus youngii sp. nov. Su :ker Creek, UMMP Holotype No. 18367.-Fig. 14-16. Arbutus trainii Mac(initie. Sucker Creek, UMMP No. 44847.-Fig. 17. Equisetum miocenicum sp. nov. Trout Creck, UMMP Holotype No. 17232. 
Fxamination of Berry's original specimen indicated that it is similar to the Sucker Creek and Trout Creek material, as suggested by Chaney and Axelrod (1959), but that these do not represent leaves of Ptelea. Ptelea trifoliata L. (the suggested affinity for $P$. miocenica), is a trifoliate leaf in which the 2 lateral leaflets are sessile or nearly so. Although the base is missing from Berry's specimen, the leaf from Trout Creek (Fig. 11) has a distinct petiole $3 \mathrm{~cm}$ in length. If the 2 lateral leaflets were removed from a leaf of $P$. trifoliata, the terminal leaflet would appear as a simple petiolate leaf, but there are no suggestions of leaflet scars, and the specimen apparently represents a simple petiolate leaf. Another difference is that the base of the terminal leaflet of Ptelea is cuneate, that is, the lamina extends down along the petiole, whereas the leaf base of the fossils are truncate. Also, the tertiary veins of the specimens diverge at approximately right angles from the secondaries and form relatively coarse ladderlike connections between them, while the secondary venation of Ptelea leaflets is a fine reticulum.

During an examination of other material from Sucker Crcek and Trout Creek, some fruits were found which compared closely with those of the genus Hiraca (Malpighiaceae). Study of herbarium material indicated that leaves of this genus were also similar to the fossil specimens discussed above. On the basis of the similarity between the leaves and fruits of Hiraea and the fossil specimens, the material from Sucker Creek and Trout Creek, together with Berry's specimen, is transferred to this genus.

Hiraea is a tropical American genus of about 30 species. The leaf fossils most closely resemble $H$. quapara (Aubl.) Morton. The fruits are also similar to this species, but may be produced by others, such as $H$. spicigera Turcz. and $H$. obovata (H. B. \& K.) Ndzu. Hiraea quapara is a woody vine growing in moist thickets and forests near sea level. It is known from British Honduras, Costa Rica, Panama, Columbia, and the Guianas (Standley and Steyermark, 1946). The presence of this tropical plant in the predominantly temperate Sucker Creek and Trout Creek floras is difficult to explain, but the presence of Oreopanax in these same floras indicates that the tropical element was represented.

Hiraea leaves have also been reported from the Oligorene of Panama (H. oligocaenica Berry, 1919) and the Eocene of 'Temnessee (H. wilcoxiana Berry, 1916, 1930).

Sucker Creek-2 specimens (1 leaf, 1 fruit), Trout Creek-2 specimens (1 leaf, 1 fruit).

Other Occurrences-Latah flora.

Symonymics-In addition to the synonymies cited, there are a few other instances in which 2 or more fossil species described from the Sucker Creek and/or Trout Creek floras appear synonymous. These are listed below under the valid name.
Family Meliaceae

Cedrela pteraformis (Berry) Brown

C. trainii Arnold. 1936a. Amer. Midl. Nat. 17, p. 1019, Fig. 11.

Arnold, C. A. 1937. Contrib. Univ. Mich. Mus. Paleo. 5 , p. 95 , pl. 6, Fig. 1-3, 6 .

Chaney, R. W., and D. I. Axelrod. 1959. Carnegie Inst. Wash. Publ. 617, p. 189, pl. 38, Fig. 3, 5-9.

MacGinitie, H. D. 1962. Univ. Calif. Publ. Geol. Sci 35, p. 114, pl. 3, Fig. 3; pl. 6, Fig. 3; pl. 7, Fig. 1.

The first name applied to fossil remains of Cedrela from the Columbia Plateau region was Carpolithus pteraformis Berry (1929a). Later, Berry (1929b) transferred this species to Gordonia pteraformis (Berry) Berry. In 1935, Brown noted that the specimens represented seeds of Cedrela and designated them as C. pteraformis (Berry) Brown. The fossils were from the Latah formation of Washington and Idaho.

Arnold (1936a) described Cedrela trainii from Sucker Creek. Chaney and Axelrod (1959) synonymized 10 additional taxa with $C$. trainii and recognized 2 species of Cedrela in Miocene deposits of western North America: C. pteraformis from the Latah flora, and C. trainii from the Sucker Creek, Bridge Creek, Trout Creek, Mascall, Stinking Water, Upper Cedarville, Lower Idaho (Hog Creek), and Thorn Creek floras.

These 2 fossil species are synonymized in the present study for several reasons. The seeds, leaflets, and capsules of Cedrela are similar among several living species and do not possess morphological features useful in separating fossil specimens. Chaney and Axelrod (1959, p. 190) and Brown (1935, p. 579) relate $C$. trainii and $C$. pteraformis, respectively, to the same modern species or species complex-C. mexicana-C. odorata. C. E. Smith $(1960)$ has synonymized these 2 living species, and, as a group, they possess all the morphological characters exhibited by $C$. trainiiC. pteraformis.

Thus, in the present study, a single species of Cedrela, C. pteraformis, is recognized in the Miocene floras of the Columbia Plateau region. This fossil species may include more than one living member of the genus, but $C$. odorata $\mathrm{L}$., as defined by C. E. Smith (1960), is probably represented. Cedrela odorata is a tree, up to $40 \mathrm{~m}$ in height, and grows in "dry to moist soils at lower elevations, frequent in second growth forest but generally cut in the West Indies and Central America before they become very large; ranging from northern Mexico and the West Indies to the Amazon drainage of Brazil." A distribution map of the species is given by C. E. Smith (1960, p. 313).

Sucker Creek-282 specimens (252 seeds, 22 leaflets, 8 capsules).

Other occurrences-Mascall, Stinking Water, Upper Cedarville, Lower Idaho (Hog Creek), Thorn Creek, Latah. 
TABLE 1. Species composition of the Sucker Creek flora. Names in parentheses refer to modern species that are similar in morphology to the fossils and thus presumedly represent the living equivalents

Megafossils

Equisetaceac

Equisetum octangulatum Smith

Blechnaceae

Woodwardia deflexipinna Smith (W.virginica [L.] Smith)

Cupressaceae

Thuja dimorpha (Oliver) Chaney and Axelrod (T.occidentalis L.; T. plicata D. Don.)

Ginkgoaceae

Ginkgo adiantoides (Unger) Heer (G. biloba L.)

Pinaceae

Picea lahontense MacGinitie (P. engelmanii Engelm.; $P$. glauca Voss)

Picea magna MacGinitie

Pinus harneyana Chaney and Axelrod (Pinus taeda L.; P. ponderosa group)

Pinus sp. (male cones)

Taxodiaceace

Glyptostrobus oregonensis Brown (G. pensilis [Staunton] Koch)

Typhaceae

Typha lesquereuxi Cockerell (T. angustifolia L.; T. latifolia L.)

Aceraceae

Acer bendirei Lesquereux (A. saccharinum L.)

Acer glabroides Brown (A. rubrum L.)

$A$ cer columbianum Chaney and Axelrod (A. glabrum Torrey)

Acer minor Knowlton (A. negundo L.)

Acer oregonianum Knowlton (A. macrophyllum Pursh)

Acer scoltiae MacGinitie (A. pictum group)

Aquifoliaceae

Ilex fulva MacGinitie ((I. aquifolium L.; I. dipyrena Wall)

Araliaceae

Oreopanax precoccinea (Brooks) Arnold (O.floribundum group)

Berberidaceae

Mahonia malheurensis Arnold (M. fortunei Scheider; $M$. confusa Sprague)

Mahonia reticulata (MacGinitie) Brown ( $M$. repens [Lindley] D. Don; M. nervosa [Pursh] Nuttall)

Mahonia simplex (Newberry) Arnold ( $M$. baeli Carrière)

Betulaceae

Alnus hollandiana Jennings (A. rhombifolia Nuttall; A. rugosa Sprengel; A. crispa Koch)

Alnus relatus (Knowlton) Brown (A. maritima [Marsh.] Muhl.)

Betula fairii Knowlton (B. luminifera Blume)

Betula thor Knowlton (B. papyrifera Marshall)

Betula sp. (seeds)

Ostrya oregoniana Chaney (O. virginiana [Miller] Koch)

Caprifoliaceae Symphoricarpus salmonensis Brown (S. albus Blake; S. racemosus Michaux; S. orbiculatus Moench)

Cornaceae Cornus ovalis Lesquereux (C. californica $\dot{\mathrm{Mey}}$; C. alternifolia $\mathbf{L}$.)

Ebernacea

Diospyros oregoniana (Lesquereux) Chaney and Axelrod (D. virginiana L.; D. kaki L.)

Ericaceae

Arbutus trainii MacGinitie (A. menziesii Pursh; A. xalapensis H.B.K.)

Fagaceae

Castanea spokanensis (Knowlton) Chaney and Axelrod (C. dentata [Marsh.] Borkhausen)

Fagus washoensis LaMotte ( $F$. grandifolia Ehrhardt)

Lithocarpus klamathensis (MacGinitie) Axelrod (L. densiflora [H. \& A.] Rehder)

Quercus consimilis Newberry (Q. myrsinaefolia Blume; Q. stenophylla Makino)

Quercus dayana Knowlton (Q.virginiana group)

Quercus eoprinus Smith (Q. montana L.)

Quercus hannibali Dorf (Q. chrysolepis Liebmann)

Quercus simulata Knowlton

Quercus sp. (acorns)

Juglandaceae

Pterocarya mixta (Knowlton) Brown (P. stenoptera DC.; P. caucasica Mez)

Lauraceae

Persea pseudocarolinensis Lesquereux (P. borbonia [L.] Sprengel; $P$. pubescens [Pursh] Sargent)

Sassafras columbiana Chaney and Axelrod (S. officinale Nees and Eberm.)

Leguminosae

Gymnocladus dayana (Knowlton) Chaney and Axelrod (G. dioica Koch) 
Leguminosae (pods)

Magnoliaceac

Magnolia ovulata Graham

Malpighiaceac

Hiraea knowltoni (Berry) Graham (H. quapara [Aubl.] Morton)

Malvaceae

Anoda suckerensis Graham (A. cristata [L.] Schlecht.)

Meliaceae

Cedrela pteraformis (Berry) Brown (C. odorata L.)

Nyssaceae

Nyssa copeana (Lesquereux) Chaney and Axelrod (N. sylvatica Marshall)

Nyssa hesperia Berry (N. aquatica Marshall)

Oleaceae

Fraxinus coulteri Dorf ( $F$. americana L.; $F$. oregona Nuttall)

Platanaceae

Platanus dissecla Lesquereux ( $P$. racemosa Nuttall)

Platanus youngii Graham

Rosaceae

Amelanchier couleeana (Berry) Brown (A. alnifolia Nuttall)

Crataegus gracilens MacGinitie (C. boyntonii Beadle)

Pyrus mckenziei Arnold (P. prunifolia group)

Rutaceae

Ptelea miocenica Berry (P. trifoliata L.)

Salicaceae

Populus eotremuloides Knowlton (P.trichocarpa T. \& G., P. balsamifera L.)

Populus lindgreni Knowlton (P. heterophylla L.)

Populus payettensis (Knowlton) Axelrod ( $P$. angustifolia James)

Salix succorensis Chaney and Axelrod (Salix nigra Marsh.; S. longipes Ander.; S. bonplandiana Kunthe)

Saxifragaceae

Hydrangea bendirei (Ward) Knowlton (H. bretschneideri Dippel; H. asper Don; $H$. chinensis Maxim.; $H$. umbellata Rehder)

Simarubaceae

Ailanthus indiana (MacGinitie) Brown (A.altissima [Mill.] Swingle)

Tiliaceae

Tilia aspera (Newberry) LaMotte (T. americana L.)

Ulmaceae

Ulmus newberryi Knowlton (U. americana L.)

Ulmus owyhensis Smith

Ulmus paucidentata Smith (U. alata Michaux)

Ulmus speciosa Newberry (U.racemosa Thomas)

Zelkova oregoniana (Knowlton) Brown (Z. serrata Maxim.; Z. ulmoides Schneider)

Hydrodictyaceae

Microfossils

Pediastrum

Eumycophyta (fungal spores)

Types 1-8

Lycopodiaceae

Lycopodium

Blechnaceze

Woodwardia

Davalliaceae

Davallia solidites Graham (D. solida [Forster] Swartz)

Osmundaceae

Osmunda claytonites Graham (O. claytoniana L.)

Polypodiaceae

Polypodium

Ephedraceae

Ephedra

Pinaceae

Abies

Picea

Pinus

Tsuga

Taxodiaceae-Taxaceae-Cupressaceae (pollen not distinguishable) 
Microfossils

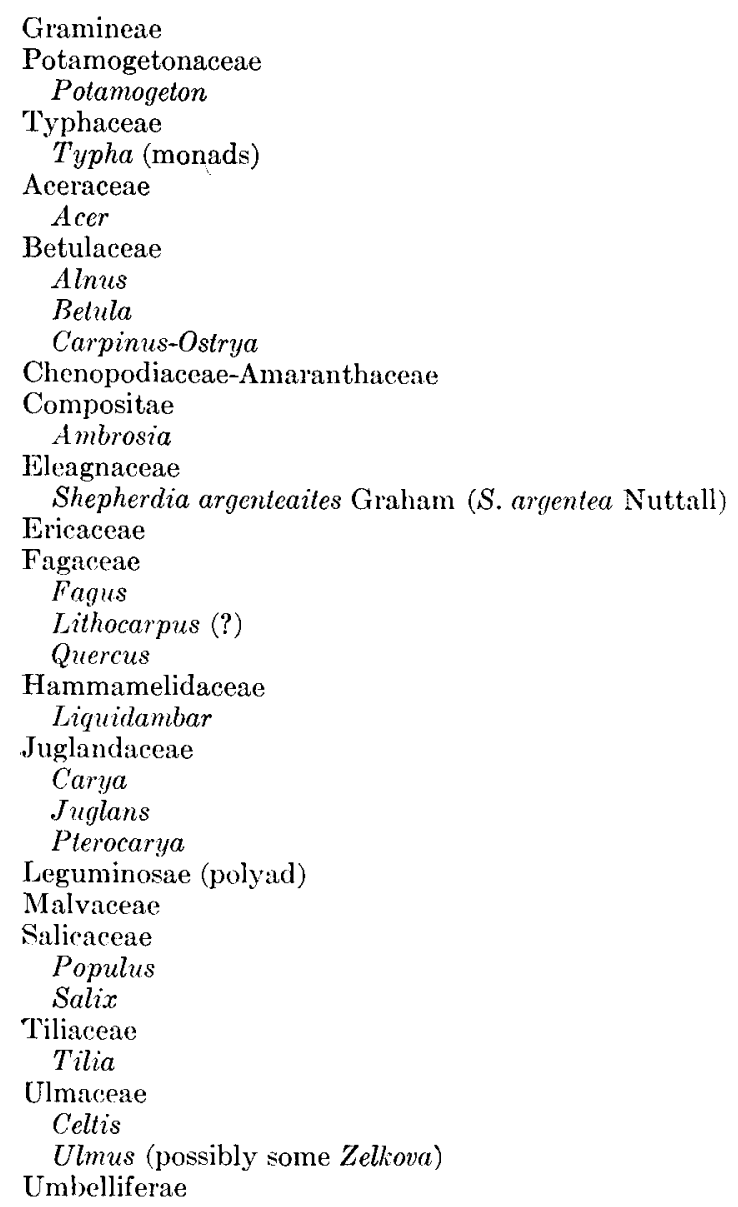

Family Rosaceae

\section{Amelanchier couleeana (Berry) Brown}

A. magnifolia Arnold. 1937. Contrib. Univ. Mich. Mus. Paleo. 5, p. 89, pl. 4, Fig. 1, 4.

The nomenclatorial situation concerning Amelanchier magnifolia and A. couleeana is similar to that of Cedrela trainii and C. pteraformis in that 2 fossil species can be matched by variations in the leaves of a single living species. The modern $A$. alnifolia Nuttall produces large leaves of the "magnifolia" type under mesic conditions, while under more xeric conditions it produces leaves of the "couleeana" type. There would be some justification in recognizing the 2 species, if various fossil floras contained one or the other type, but at Trout Creek both are represented, and the two are connected by a series of intermediates. If 2 species are recognized, about 15 . Trout Creek specimens must be assigned to one or the other group in a completely arbitrary manner. For this reason, $A$. magnifolia has been synonymized with A. couleeana.

Sucker Creek-4 specimens, Trout Creek, 215 specimens. Other occurrences-Mascall, Lower Idaho, Thorn Creek, Latah.

Incertae Sedis-Chaney and Axelrod (1959), in their consideration of the Mascall, Stinking Water, and Blue Mountains floras of the Columbia Plateau region, have considered incidentally other associated floras, including the Sucker Creek and Trout Creek floras. They have included several species under Incertae Sedis. This list, as it pertains to the Sucker Creek and Trout Creek floras, has been checked, and the author is in agreement with Chaney and Axelrod in their assignment of the 2 specimens to Incertae Sedis. Rhus diluvialis is added to the list and will be discussed below.

Dipteronia insignis Brown. Smith, H. V. 1938. Bull. Torr. Bot. Club 65, p. 561, pl. 28, Fig. 7. Populus alexanderi Dorf. Smith, H. V. 1939b. Papers Mich. Acad. Arts, Sci., and Letters 24, p. 110. 
Rhus diluvialis Arnold. 1937. Contrib. Univ. Mich. Mus. Paleo. 5, p. 93, pl. 5, Fig. 4.

The identity of this specimen was questioned by Brown (1937) who thought it probably represented Acer. Chaney and Axelrod (1959, p. 191) accepted this interpretation and synonymized $R$. diluvialis with Acer bendirei Lesquereux.

The specimen differs from Rhus, especially $R$. trilobata Nuttall, with which it was originally compared (Arnold, 1937). It is larger and the serrations are more acute, as compared to the rounded serrations of Rhus. It differs from Acer, however, in its decurrent leaf base. The leaf blade of Acer does not continue along the petiole to near the point of attachment and in this respect the fossil is more similar to Rhus than to Acer. Since positive identification has not yet been made, the specimen is placed under Incertae Sedis.

Species rejected from the Sucker Creek Flora (Chaney and Axelrod, 1959)-Pinus sp. Brooks. 1935. Ann. Carnegie Mus. 24, p. 281, pl. 4, Fig. 1, 4,5 .

Additional taxonomic changes-A final taxonomic change suggested for the Sucker Creek flora concerns the resurrection of Arbutus trainii MacGinitie from the list of synonymies given by Chaney and Axelrod (1959).

\section{Family Ericaceae (Fig. 14-16)}

\section{Arbutus trainii MacGinitie}

MacGinitie, H. D. 1933. Carnegie Inst. Wash. Publ. 416, p. 64, pl. 12, Fig. 3; pl. 13, Fig. 1, 2.

The material originally described from Trout Creek by MacGinitie (1933) as Arbutus was synonymized with Gordonia idahoensis (Knowlton) Berry by Chaney and Axelrod (1959). MacGinitie (oral communication, 1961) is not in agreement with this treatment and considers Arbutus trainii a valid member of the Trout Creek flora. It is also known from Sucker Creek.

Herbarium material of the 2 genera was examined, and differences were noted in the tertiary venation, nature of the leaf bases, and petiole length. The tertiary venation of Gordonia is a coarse reticulum whereas that of Arbutus is finer. The lamina of Gordonia is decurrent on the petiole almost to the point of attachment to the stem, resulting in an oblanceolate leaf with a relatively short petiole (less than $2 \mathrm{~cm}$ ). Leaves of Arbutus are more elliptic and have longer petioles (ca. 3.5 $\mathrm{em})$. Differences in the marginal dentations cited by Chaney and Axelrod (1959, p. 198-roundedcrenate in Cordonia, and serrate in Arbutus) did not appear to be consistent. On the other hand, leaves of modern species of Arbutus in the University of Michigan Herbarium matching the fossils exactly could not be found. It was concluded, however, that as far as the Sucker Creek and Trout Creek specimens are concerned, they are more similar to Arbutus.
The leaves of $A$. trainii are similar to several living species. In the Michigan herbarium, specimens of $A$. xalapensis H. B. \& K. match the fossil specimens closely. This species presently grows on wooded slopes, often in dense pine-oak forests, in northern Mexico. The specimens also compare closely with $A$. menziesii Pursh.

It is not possible to list all occurrences of $A$. trainii in other Miocene floras because of their frequent synonymy with Gordonia. Detailed monographic studies on the fossil members of the 2 genera in all of the floras in which they are represented will be necessary before an accurate account of their fossil history can be presented. It is intended that only the specimens of $A$. trainii from Sucker Creek and Trout Creek be removed from the list of synonymies given by Chaney and Axelrod (1959, p. 197).

Sucker Creek-43 specimens; Trout Creek-152 specimens.

The TROUT CREEK Flora-The first extensive investigation of fossil plants from Trout Creek was made by MacGinitie (1933). In his study MacGinitie recognized 25 families, 37 genera, and 45 species. Arnold (1936b, 1937) added 8 new species that are presently recognized. Chaney and Axelrod (1959) list 22 families, 39 genera, and 53 species for the flora. From 'Train's collections at the University of Michigan, 6000 well-preserved specimens were selected for study. Several species represented only in the University of California collections were also included, and from the total number of specimens, 29 families, 51 genera, and 75 species were recognized in the study.

The Trout Creek material at the University of Michigan came from one locality in southern Harney County, Oregon. Train uncovered 4 sites on the same hillside within a few hundred feet of one another, but almost all the specimens came from a site designated by Train as the 'West Quarry.' These specimens are marked with a $W$ followed by a number indicating the level from which the specimens were collected.

The prominent physiographic feature in the immediate vicinity of the collection localities is Flagstaff Butte, an eroded volcanic plug, which rises to a height of about $6000 \mathrm{ft}$. To the south are the Trout Creek Mountains $(8000 \mathrm{ft}$ ) and to the north the Sheepshead Mountains (6000 ft). Between the mountains is a relatively flat expanse of sagebrush desert about 2:5 miles long. The relatively high elevation of this desert (ca. $4300 \mathrm{ft}$ ) reduces the contrast between plain and mountain so that the highlands in many places appear as rather low-lying hills. The collecting site is in the extreme southern portion of the flatland, near the northern foothills of the Trout Creek Mountains, and east of Flagstaff Butte.

Species descriptions - The following new species are proposed for the Trout Creek fiora. 
Table 2. Species composition of the Trout Creek flora. Names in parentheses refer to modern species that are similar in morphology to the fossils and thus presumedly represent the living equivalents. The sediments were barren of pollen and spores

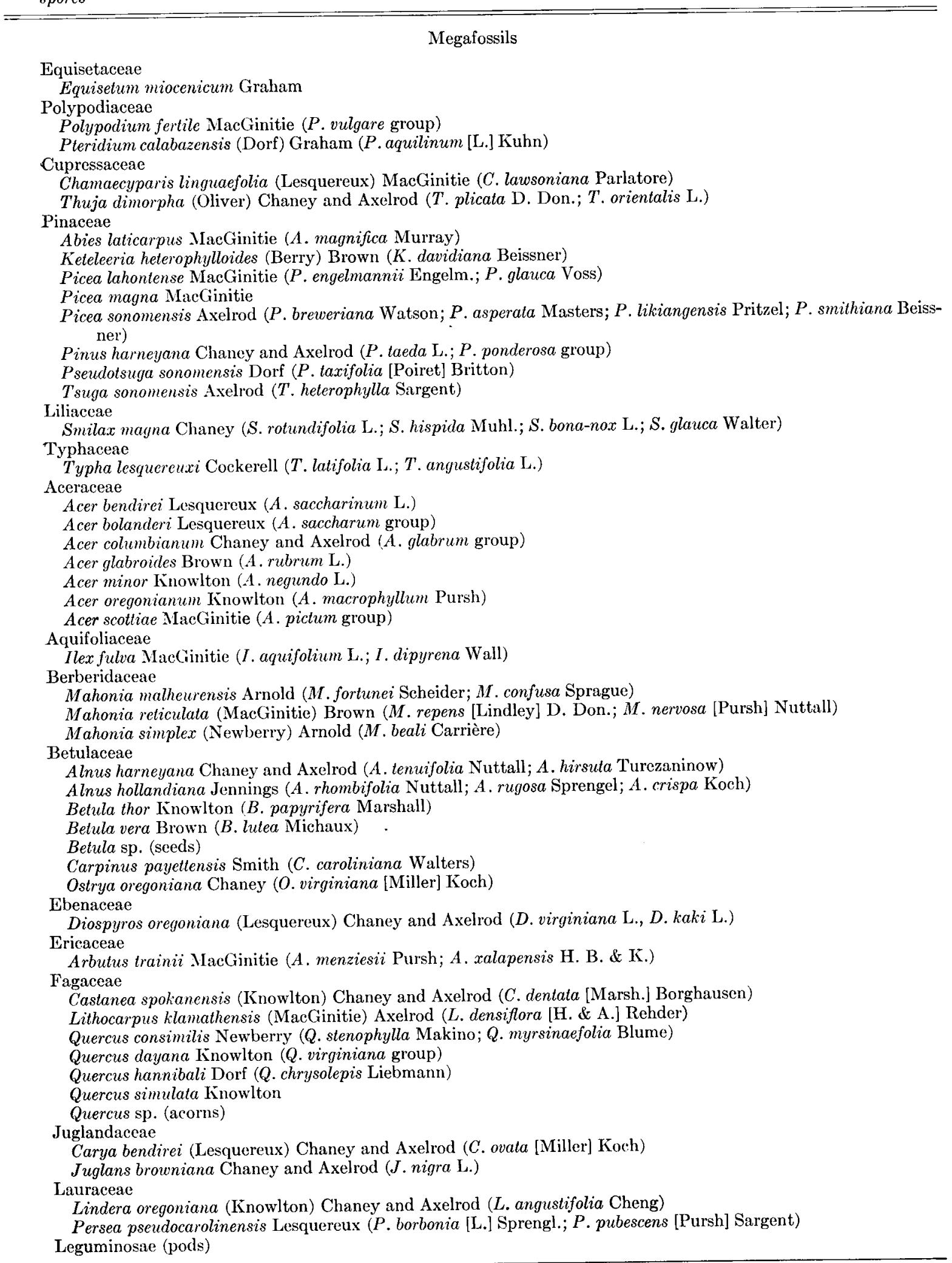




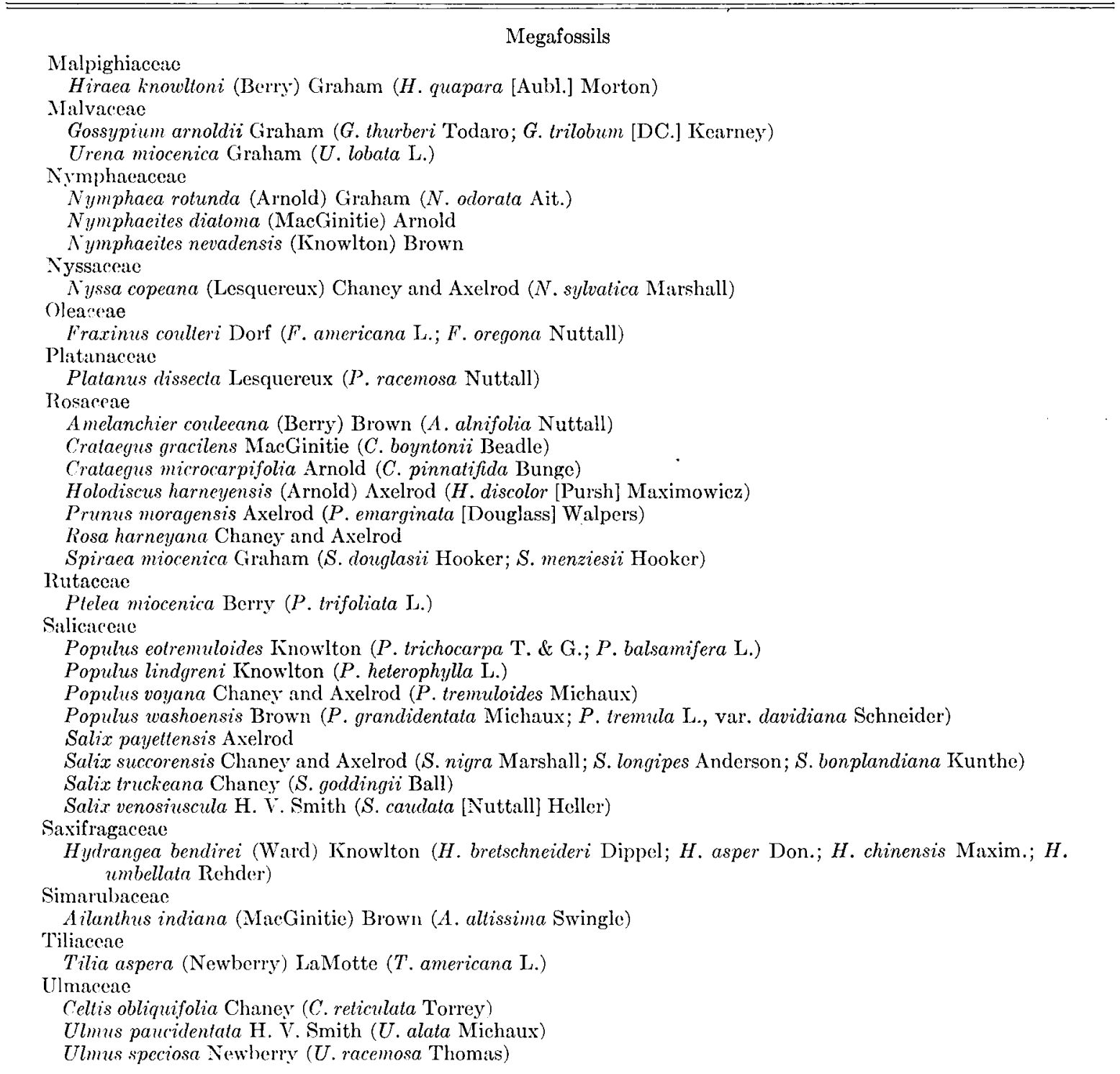

Division Tracheophyta

Sub-Division Sphenopsida

Order Equisetales

Family Equisctaceae

Equisetum miocenicum sp. nov. (Tig. 17)

Synonymy-Equisetum sp. Arnold. 1937. Contrib. Univ. Mich. Mus. Paleo. 5, p. 82, pl. 1, Fig. 1. Chaney, R. W. and D. I. Axelrod. 1959. Carnegie Inst. Wash. Publ. 617, p. 115.

Species diagnosis--Specimen $13.5 \mathrm{~cm}$ in length, $1.4 \mathrm{~cm}$ greatest diameter, tapering toward base, numerous longitudinal ribs, stem divided into nodes and internodes by whorls of microphyll scars, internode length ea. $1 \mathrm{~cm}$ at base, increasing to $4.5 \mathrm{~cm}$ between nodes 5 and 6 (numbering from bottom); root and branch scars present near base, branch scars only near apex; nodal sheaths narrow in relation to width, more distinct near apex, teeth inconspicuous, irregular spherical marks at nodes 3 and 5 possibly representing small tubers.

Dr. R. L. Hauke, University of Rhode Island, has examined the fossil specimens of Equisetum and has provided much helpful information concerning these plants.

A specific name has been assigned to the Trout Creek stem specimen to distinguish it from a rhizome found at Sucker Creek, a distinction not evident when both are referred to Equisetum sp. Equisetum miocenicum was a marsh plant. This interpretation is based on the presence of branches and roots near the base of the specimen and struc- 
tures suggestive of blue-green algal sheaths. These features indicate that the lower portion of the specimen grew submerged in water, rather than being underground.

Trout Creek-1 specimen, UMMP Holotype No. 17232

$$
\text { Sub-Division Pteropsida }
$$

Class Angiospermae

Order Malvales

\section{Family Malvaceae}

\section{Gossypium arnoldii sp. nov. (Fig. 9)}

Species diagnosis-Tripalmately lobed, median lobe $4.3 \times 1.3 \mathrm{~cm}$, lateral lobes $3.5 \times 1 \mathrm{~cm}$, tips acute; sinus between lobes acute; entire margined; auriculate, auricles 2 , opposite, located at the base of the leaf, small, tips blunt; tripalmately veined (2 additional veins serving the auricles), median veins straight, unbranched, extending to tips of Jobes, secondaries sub-oppositely arranged, diverging at ca. $40^{\circ}$ angle, thin, slightly sinuous, curving upward near the margin and faintly camptodrome, tertiary venation a fine reticulum; medium texture.

A study of the modern species of Gossypium indicated a close similarity with the fossil specimen from Trout Creek. It is described as $G$. arnoldii, and is named for Professor C. A. Arnold of the University of Michigan.

The fossil resembles several species in the modern flora, including G. thurberi Todaro and $G$. trilobum (L.) Kearney. The living species resembling the fossils grow in southwestern United States (Arizona, Wyoming, Texas) and northern Mexico (Sonora, Jalisco, southwestern Chihuahua). They are usually found at elevations between 5000-6000 ft, but many grow in localities as high as $7000 \mathrm{ft}$ or as low as $2000 \mathrm{ft}$. They commonly grow along washes, rock ledges, and canyon walls.

Trout Creek-2 specimens, UMMP Holotype No. 44857

Urena miocenica sp. nov. (Fig. 6, 7)

Species diagnosis-Leaf $3.2 \times 2.9 \mathrm{~cm}$ (petiole not preserved); trilobate, central lobe extending beyond laterals, $2.5 \mathrm{~cm}$ in length; base auriculate, apex rounded, margin finely toothed; venation tri- to pentapalmate, depending on number of smaller basal lobes, primary veins straight, extending to apex of lobes, first major secondaries departing above mid-point of median primary vein, straight or slightly looping, departing at about $45^{\circ}$ angle, tertiary venation a fine reticulum; medium texture.

Urena is a tropical to subtropical genus of 3 species. The Trout Creek specimen most closely resembles $U$. lobata L., which grows under a variety of ecological conditions. It is common in low wet ground, but also occurs in relatively dry habitats. It extends from Florida southward into
Panama, British Honduras, Bolivia, Brazil, Puerto Rico, British Guiana, and occurs in Hawaii and the Philippine Islands, and in China (Fukien and Chekiang Provinces). It often grows at altitudes between 1000 and $2000 \mathrm{ft}$. There is no other record of Urena in the fossil floras of America.

Trout Creek-2 specimens, UMMP Holotype No. 4494i

\section{Family Rosaceae}

Spiraea miocenica sp. nov.

Synonymy-Spiraea(?) sp. MacGinitie. 1933. Carnegie Inst. Wash. Publ. 416, p. 56, pl. 9, Fig. 1.

MacGinitie (1933) has described a single leaf found in the Trout Creek flora as Spiraea (?) sp. A holotype was designated and a description given, but a specific name was not assigned. Comparison with herbarium material indicated that this specimen is a valid Spiraea and is distinct from others that have been described. The name Spiraea miocenica has been chosen for the specimen and is assigned to distinguish the Trout Creek specimen from others in the Columbia Plateau region, such as S. harneyana Chaney and Axelrod. MacGinitie's original specimen serves as the holotype and his description, quoted below, is used as the species diagnosis:

Leaf oblong-ovate; length $4.4 \mathrm{~cm}$, width $1.5 \mathrm{~cm}$; apex slender-obtuse; base cuneate; petiole fragmentary, slender, $3 \mathrm{~mm}$. long; margin entire in the lower half or two-thirds, the upper part coarsely dentate with a few forward pointing teeth; midrib stout but somewhat irregular and tapered to a fine thread at the apex; about eight pairs of alternate or subopposite secondaries at an angle of $45^{\circ}$ in the middle part of the leaf, $50^{\circ}$ to $60^{\circ}$ apically, curving upward and camptodrome where the margin is entire and entering the teeth above; tertiaries more plentiful toward the margin of the leaf, at right angles with the secondaries; areolation fine polygonal; texture subcoriaceous.

Spiraea miocenica is similar to several modern members of the genus, including $S$. douglasii Hooker and S. menziesii Hooker (MacGinitie, 1933, p. 56). These living species presently occur as members of the Upper Transition forests of western North America.

Trout Creek-UC_(Berkeley) collections, Holotype No. 592 .

New combinations - The following new combinations are proposed for Trout Creek species.

\section{Family Polypodiaceae}

Pteridium calabazensis (Dorf) comb. nov. (Fig. 4)

Synonymy-Pteris calabazensis Dorf. 1930. Carnegie Inst. Wash. Publ. 412, p. 67, pl. 5, Fig. $1,2$.

Áxeirod, D. I. 1939. Carnegie Inst. Wash. Publ. 516, p. 85, pl. 6, Fig. 1. . 1944. Carnegie Inst. Wash. Publ. 553, p. 190.

Smith, H. V. 1939a. Bull. Torr. Bot. Club 66, p. 467 , pl. 12, Fig. 2. 
Pteris idahoensis (Knowlton) Brown. 1940. Jour. Wash. Acad. Sci. 30, p. 345 (see synonymy).

Chaney, R. W., and D. I. Axelrod. 1959. Carnegie Inst. Wash. Publ. 617, p. 223 (see synonymy).

Pteris silvicola Hall. In: Chaney, R. W. 1927. Carnegie Inst. Wash. Publ. 346, p. 100, pl. 8, Fig. 2, 4-7.

Dryopteris idahoensis Knowlton. 1898. 18th Ann. Rept. U. S. Geol. Surv., part 3, p. 721-722, pl. 99, Fig. 1, 2.

Berry, E. W. 1934. U. S. Geol. Surv. Prof. Paper 185-1, p. 103, pl. 19, Fig. $2,3$.

Dorf, Erling. 1938. Carnegie Inst. Wash. Publ. 476, p. 105.

The acceptance of the distinction between Pteridium and Pteris by most pteridologists requires a nomenclatorial change for the fossil species of the bracken fern, since these have been described or transferred to the genus Pteris. Hence the new combination, Pteridium calabazensis, is proposed for these fossils.

Pteridium calabazensis is the fossil equivalent of the modern $P$. aquilinum (L.) Kuhn. The living species grows in open woods, thickets, burned areas, and clearings and is widespread throughout North America, Europe, and eastern Asia. In England certain varieties have such broad ecological tolerances that they have developed weedy tendencies to the extent that populations have been artificially infected with fungi in an effort to control their growth in cultivated areas.

Trout Creek-1 specimen.

Other occurrences-Payette, Thorn Creek, Bridge

Creek, Tehachapi (Miocene, California, Axelrod,

1939), Sonoma (Pliocene, California, Axelrod, 1944), lower Idaho (Weiser flora in Dorf, 1938).

\section{Family Nymphaeaceae}

\section{Nymphaea rotunda (Arnold) comb. nov. (Fig. 5)}

Synonymy-Nymphaeites rotundus Arnold. 1937. Contrib. Univ. Mich. Mus. Paleo. 5, p. 84, text-fig. 1

Chaney, R. W., and D. I. Axelrod. 1959. Carnegie Inst. Wash. Publ. 617, p. 116.

Fossil specimens of the Nymphacaceae are represented at Trout Creek by leaves and rhizomes bearing sears of detached roots. Arnold (1937) described certain of the leaf material as Nymphaeites rotundus. The generic name Nymphaeites was used because at the time of Arnold's treatment, Nymphaea and Castalea were recognized as separate genera and could not be distinguished on the basis of leaf morphology. These 2 genera have since been united and the fossil material can be referred to Nymphaea rotunda (Arnold) comb. nov.

Nymphaea rotunda is similar to the common water lily, $N$. odorata Ait. This species is widespread in shallow fresh-water lakes and streams in eastern and central United States and southern Canada.
Trout Creek-1 specimen, UMMP Holotype No. 18373.

Incertae Sedis-The following species have been referred to Incertae Sedis by Chaney and Axelrod (1959).

Leguminosites sp. MacGinitie. 1933. Carnegie Inst. Wash. Publ. 416, p. 64, pl. 7, Fig. 4.

Saussurea (?) sp. MacGinitie. 1933. Carnegie Inst. Wash. Publ. 416, p. 67, pl. 16, Fig. 1.

Vincetoxicum (?) trinervata MacGinitie. 1933. Carnegie Inst. Wash. Publ. 416, p. 66, pl. 15, Fig. 1.

A REVISED SPECIES LIST FOR THE SUCKER CREEK AND TROUT CREEK FLORAS-The results of Tertiary paleobotanical studies are applicable to a wide variety of investigations. Geologists interested in the relative age of sediments often use paleobotanical evidence for stratigraphic correlations. Fossil floras also provide data concerning the paleoenvironmental conditions of a region. This includes not only the paleoclimate, but also the paleo-physiography (cf. Axelrod, 1957), continental drift and land bridges, polar wandering, and paleo-magnetism. Other uses of Tertiary paleobotany include studies of the origin and migration of plants, previous hybridization between plants now allopatric in distribution, evolutionary trends, rates of evolution, and various other subjects. Regardless of the application of the data, however, 1 criterion is essential if conclusions are to be based on sound evidence: there must be a reliable and relatively complete species list for the floras involved.

The proposed systematic changes for the Sucker Creek and Trout Creek floras have been presented. With these revisions available, it is now possible to summarize the composition of the 2 floras. The species lists for the Sucker Creek and Trout Creek floras are given in Tables 1 and 2, respectively, together with suggested living equivalent(s). As noted earlier, interpretations and consideration of the significance of these fossil plants in southeastern Oregon will be presented in a later publication.

\section{LITERATURE CITED}

Arnold, C. A. 1936a. The occurrence of Cedrela in the Miocene of Western America. Amer. Midl. Nat. 17: 1018-1021.

- $1936 \mathrm{~b}$. Some fossil species of Mahonia from the Tertiary of eastern and southeastern Oregon. Contrib. Univ. Mich. Mus. Paleo. 5: 57-66.

- 1937. Observations on the fossil flora of eastern and southeastern Oregon. I. Contrib. Univ, Mich. Mus. Paleo. 5: 79-102.

Axelrod, D. I. 1939. A Miocene flora from the western border of the Mohave Desert. Carnegie Inst. Wash. Publ. 516. 129 p.

1944. The Sonoma flora. Carnegic Inst. Wash. Publ. 553: 167-206.

- 1957. Paleoclimate as a measure of isostacy. Amer. Jour. Sci. 255: 690-696. 
Berry, E. W. 1916. The Low er Eocene floras of southeastern North America. U. S. Geol. Surv. Prof. Paper 91 .

Zone. U. S. Natl. Mus. B3ull. 102: 15-44.

- 1929a. A revision of the flora of the Latah Formation. U. S. (icol. Surv. Prof. Paper 154-H.

- 1929b. Gordonia from the Miocene of Idaho and Washington. Amer. Jour. Sci. 18: 429-432.

- 1930. Revision of the lower Eocene Wilcox flora of the southeastern states; with descriptions of new species, chiefly from Temmessee and Kentucky. U. S. Geol. Surv. Prof. Paper 156.

- 1931. A Miocene flora from Grand Coulee, Washington. U.S. Geol. Surv. Prof. Paper 170-C.

- 1934. Miocene plants from Idaho. U. S. Geol. Surv. Prof. Paper 155-E.

Brooks, B. W. 1935. Fossil plants from Sucker Creek, Idaho. Ann. Carnegie Mus. 24: 275-336.

Brown, R. W. 1935. Niocene leaves, fruits, and seeds from Idaho, Oregon, and Washington. Jour. Palco. 9: $572-587$.

- 1937. Further additions to some fossil floras of the western United States. Jour. Wash. Acad. Sci. 27: $506-517$.

- 1940. New species and changes of names in some Amorican fossil floras. Jour. Wash. Acad. Sci. 30: $344-356$.

. 1946. Nlterations in some fossil and living floras. Jour. Wash. Acad. Sci. 36: 344-355.

Cilaney, R. W. 1927. Geology and palcontology of the Crooked River IBasin, with special reference to the Bridge Creek flora. Carnegie Inst. Wash. Publ. 346 : $45-138$.
ANd D. I. Axelrod. 1959. Miocene fioras of the Columbia Plateau. Carnegie Inst. Wash. Publ. 617. $237 \mathrm{p}$.

Dorf, E. 1930. Pliocene floras of California. Carnegie Inst. Wash. Publ. 412: 1-112.

- 1938. A Late Tertiary flora from southwestern Idaho. Carnegie Inst. Wash. Publ. 476: 73-124.

KNowltox, F. H. 1898. The fossil plants of the Payette Formation. U. S. Geol. Surv. 18th Ann. Rept., pt. 3, p. $721-744$.

—_. 1899. Fossil flora of the Yellowstone National Park. U.S. Geol. Surv. Monogr. 32, pt. 2: 651-882.

LAMotтe, R. S. 1952. Catalogue of Cenozoic plants of North America through 1950. Geol. Soc. Amer. Mem. 51.

MacGinimie, H. D. 1933. The Trout Creek flori of southeastern Orcgon. Carnegie Inst. Wash. Publ. 416 : 21-68.

- 1962. The Kilgore flora, a Late Miocene flora from northern Nebraska. Univ. Calif. Publ. Geol. Sci. 35: $67-158$.

Smith, C. E. 1960, A revision of Cedrela. Fieldiana: Bot. 29: 292-341.

Sмiтн, H. V. 1938. Some new and interesting Late Tertiary plants from Sucker Creek, Idaho-Oregon boundary. Bull. Torrey Bot. Club 65: 557-564.

- 1 1939a. A flora of East American aspect in the Miocene of Idaho. Bull. Torrey Bot. Club $66: 465^{-481}$ - 1939b. Additions to the fossil flora of Sucker Creck, Oregon. Papers Mich. Acad. Sci., Arts, Ietters 24: $107-120$.

Standiey, P. C., And J. A. Stemermark. 1946. Flora of Guatemala. Part V, p. 1-502. Chicago Nat. Hist. Mus. 